\title{
New Green Synthesis and Antineoplastic Activity of Bis (3-Arylimidazolidinyl-1) Methanes
}

\author{
María Cristina Caterina ${ }^{1}$, Isabel A. Perillo ${ }^{1}$, Ximena Villalonga ${ }^{2}$, Nicolás Amiano ${ }^{2}$ Cristian Payés $^{2}$, \\ Mercedes L. Sanchez ${ }^{2}$, Alejandra Salerno ${ }^{1^{*}}$ \\ ${ }^{1}$ Department of Organic Chemistry, Faculty of Pharmacy and Biochemistry, University of Buenos Aires, \\ Buenos Aires, Argentina \\ ${ }^{2}$ Faculty of Medicine, University of Buenos Aires, Buenos Aires, Argentina \\ Email: *asalerno@ffyb.uba.ar
}

Received September 28, 2013; revised October 28, 2013; accepted November 4, 2013

Copyright (C) 2013 María Cristina Caterina et al. This is an open access article distributed under the Creative Commons Attribution License, which permits unrestricted use, distribution, and reproduction in any medium, provided the original work is properly cited.

\begin{abstract}
A new green synthesis and anti-tumor activity of the series of bis (3-arylimidazolidinyl-1) methanes $\mathbf{1} \mathbf{- 6}$ are described. The compounds were synthesized from the corresponding $N$-arylethylenediamine and trioxane as sources of formaldehyde and the reactions were performed in heterogeneous phase catalyzed by an acidic ion-exchange resin (Amberlyst 15). The compounds were tested with the Sulforhodamine B assay according to the protocol of the National Cancer Institute for several cell lines. The results were expressed as percentage inhibition of growth cell in comparison with the full growth of the cells without treatment. Cytotoxicity on normal cells using the Annexing-PI staining and flow cytometry has been evaluated. The parent compound, bis(3-phenylimidazolidinyl-1)methane $\mathbf{1}$ and the monohalogenated derivatives 4-chlorophenyl $\mathbf{3}$ and 3-bromophenyl $\mathbf{5}$ showed antineoplastic activity, 60\%, 82\% and 89\% inhibition growth cell respectively on the human colon cell line (HCT116). The 4-tolyl derivative $\mathbf{6}$ presented inhibitory activity (73\% inhibition of growth cell) on human lung adenocarcinoma cell line (A549) and 62\% on human mammary cell line MCF-7.
\end{abstract}

Keywords: Bis (3-Arylimidazolidinyl-1) Methanes; Amberlyst-15; Anticancer Activity; Cancer Cell Lines; Sulforhodamine B

\section{Introduction}

Cancer, a diverse group of diseases characterized by uncontrolled growth of abnormal cells, is a major worldwide problem. It is a fatal disease standing next to the cardiovascular disease in terms of mortality $[1,2]$. The characterization of novel structures that can act as more effective anticancer agents is still a major challenge to medicinal chemistry researchers [3].

Symmetric bis-heterocyclic derivatives have been objects of interest due to the antitumor activities that they have showed. Among others, head-to-head benzimidazole compounds, whose activity is attributed to different mechanisms of action, have been most studied [4-6]. In other cases, a variety of heterocyclic cores are connected through linkers of different structural features. For example, bis-azepines [7], bis-isooxazoloazepanes [8], bisindenoquinolines [9] and bis-quinolinium compounds [10] have been described and evaluated.

\footnotetext{
*Corresponding author.
}

Another group of compounds have a simple methylene as linker (bis-heterocyclylmethanes). Of these, the most studied compounds are synthetic ring-substituted bis (3'indolyl) methane (DIM) analogues $[11,12]$. Other compounds are characterized by the presence of two saturated 1,3-N,X-heterocycles connected by a methylene of general formula $\mathbf{A}$ for which antitumor activity has been described. Among them, we can mention bis-imidazolidine-2,4-dione derivatives $[13,14]\left(\mathrm{X}=\mathrm{NAr}, \mathrm{Y}=\mathrm{COCH}_{2}\right.$, $\mathrm{Z}=\mathrm{CO})$, bis-oxazolidines [15] $\left(\mathrm{X}=\mathrm{O}, \mathrm{Y}=\mathrm{CH}_{2} \mathrm{CHCH}_{3}\right.$, $\mathrm{Z}=\mathrm{CH}_{2}$ ), and taurolidine [16,17] (a bisthiadiazine derivative) $\left(\mathrm{X}=\mathrm{NH}, \mathrm{Y}=\mathrm{SO}_{2} \mathrm{CH}_{2} \mathrm{CH}_{2}, \mathrm{Z}=\mathrm{CH}_{2}\right)$.<smiles></smiles>

In previous studies we reported the synthesis and antimicrobial activity of a series of novel bis (3-arylimidazolidinyl-1) methanes 1 - 6 [18], corresponding to struc- 
ture A $\left(\mathrm{X}=\mathrm{NAr}, \mathrm{Y}=\mathrm{CH}_{2} \mathrm{CH}_{2}, \mathrm{Z}=\mathrm{CH}_{2}\right)$ with two imidazolidine cores. Imidazolidines (tetrahidroimidazoles) are cyclic aminals of pharmacological interest. They have shown fungicide, bactericide, antiviral, [19-21] antiTrypanosoma cruzi [22,23] and antileshmanial activity [24]. Other properties such as anti-inflammatory [19], analgesic [19], estrogenic [25] and tumor inhibition [26, 27] activities have been also reported. On the other hand, imidazolidine nucleus is also present in fused heterocyclic compounds with pharmacological activity [28].

In line with our ongoing studies related to the synthesis and study of imidazolidines of biological interest, in this work, an efficient protocol for the synthesis of bis (3-arylimidazolidinyl-1) methanes $\mathbf{1}$ - $\mathbf{6}$ is also described (Table 1). In vitro anti-tumor activity and cytotoxicity of synthesized compounds are also presented.

\section{Experimental Section}

\subsection{General Data}

The resin was dried prior to use for $2 \mathrm{~h}$ at $80^{\circ} \mathrm{C}$. A mixture of a corresponding $\mathrm{N}$-arylethylenediamine (2.0 $\mathrm{mmol})$, trioxane $(1.0 \mathrm{mmol})$ and Amberlyst-15 $(150 \mathrm{mg})$ in DCM (dichloromethane) anh. $(10 \mathrm{~mL})$ was refluxed for an appropriate time $(15-30 \mathrm{~min})$ as indicated by TLC. The catalyst was filtered and the solvent was evaporated in vacuo, the obtained solid were crystallized from ethanol to afford compounds $\mathbf{1}$ - $\mathbf{6}$ in excellent yields $(96 \%-99 \%)$. Resin recycling: the catalyst was refluxed with DCM to remove any adsorbed material and then dried at $80^{\circ} \mathrm{C}$.

Compounds 1 - 6 were describedpreviously [18]: the new yields and spectroscopic data obtained confirming their identity shown below.

\subsubsection{Bis (3-phenylimidazolidinyl) Methane1}

Yield: $97 \%$. M. p. $141^{\circ} \mathrm{C}-143^{\circ} \mathrm{C} .{ }^{1} \mathrm{H}-\mathrm{NMR}\left(\mathrm{CDCl}_{3}\right) \delta$ ppm: 3.13 (t, 4H, $J=6.31$ ); 3.43 (t, $4 \mathrm{H}, J=6.31$ ); 3.46 (s, $2 \mathrm{H}) ; 4.16(\mathrm{~s}, 4 \mathrm{H}) ; 6.50$ (d, $4 \mathrm{H}, J=7.68) ; 6.71$ (t, $2 \mathrm{H}, J=$ $7.12) ; 7.24$ (dd, $4 \mathrm{H}, J=7.68,7.12) .{ }^{13} \mathrm{C}$ NMR $\delta$ ppm: 45.6, 50.9, 69.0, 74.4, 111.7, 113.8, 129.2, 146.5.

\subsubsection{Bis [3-(4-methoxypheny)limidazolidinyl] Methane2}

Yield: $96 \%$. M. p. $144^{\circ} \mathrm{C}-146^{\circ} \mathrm{C} .{ }^{1} \mathrm{H}-\mathrm{NMR}\left(\mathrm{CDCl}_{3}\right) \delta$ ppm: 3.12 (t, $4 \mathrm{H}, J=6.36$ ); 3.37 (t, $4 \mathrm{H}, J=6.36$ ); 3.47 (s, $2 \mathrm{H}) ; 3.75$ (s, 6H); $4.12(\mathrm{~s}, 4 \mathrm{H}) ; 6.50$ (dd, $4 \mathrm{H}, J=6.80$, 2.30); $6.83(\mathrm{dd}, 4 \mathrm{H}, J=6.80,2.30) .{ }^{13} \mathrm{C}$ NMR $\delta$ ppm: $46.4,50.9,69.7,55.8,74.7,112.7,114.9,141.5 .2,151.3$.

\subsubsection{Bis [3-(4-chloropheny)limidazolidinyl] Methane 3}

Yield: $98 \%$. M. p. $190^{\circ} \mathrm{C}-192^{\circ} \mathrm{C} .{ }^{1} \mathrm{H}-\mathrm{NMR}\left(\mathrm{CDCl}_{3}\right) \delta$ ppm: 3.12 (t, 4H, $J=6.27$ ); 3.37 (t, 4H, $J=6.27$ ); 3.44 (s, $2 \mathrm{H}) ; 4.11(\mathrm{~s}, 4 \mathrm{H}) ; 6.43$ (d, $4 \mathrm{H}, J=8.90) ; 7.17$ (d, $4 \mathrm{H}, J=$
8.90). ${ }^{13} \mathrm{C}$ NMR $\delta$ ppm: 45.8, 50.8, 69.0, 74.1, 112.6, $121.2,129.0,145.2$.

\subsubsection{Bis [3-(3,4-dichloropheny)limidazolidinyl] Methane 4}

Yield: $96 \%$. M. p. $153^{\circ} \mathrm{C}-155^{\circ} \mathrm{C} .{ }^{1} \mathrm{H}-\mathrm{NMR}\left(\mathrm{CDCl}_{3}\right) \delta$ ppm: 3.12 (t, $4 \mathrm{H}, J=6.18) ; 3.36$ (t, $4 \mathrm{H}, J=6.18) ; 3.43$ (s, 2H); 4.10 (s, 4H); 6.33 (dd, $2 \mathrm{H}, J=8.72,2.80) ; 6.56$ (s, 2H), 7.23 (d, $2 \mathrm{H}, J=8.72) .{ }^{13} \mathrm{C}$ NMR $\delta$ ppm: 45.7, 50.7, $68.8,73.1,111.2,112.9,119.0,130.5,132.8,145.6$.

\subsubsection{Bis [3-(3-bromopheny)limidazolidinyl] Methane 5}

Yield: $99 \%$. M. p. $138^{\circ} \mathrm{C}-140^{\circ} \mathrm{C} .{ }^{1} \mathrm{H}-\mathrm{NMR}\left(\mathrm{CDCl}_{3}\right) \delta$ ppm: 3.11 (t, $4 \mathrm{H}, J=6.42$ ); 3.38 (t, $4 \mathrm{H}, J=6.42$ ); 3.43 (s, $2 \mathrm{H}) ; 4.12(\mathrm{~s}, 4 \mathrm{H}) ; 6.42(\mathrm{dd}, 2 \mathrm{H}, J=7.95,2.25) ; 6.64(\mathrm{t}$, $2 \mathrm{H}, J=2.25), 6.81$ (dd, 2H, $J=7.69,2.25), 7.06$ (t, 2H, $J$ $=7.95) .{ }^{13} \mathrm{C}$ NMR $\delta$ ppm: $45.5,50.7,68.8,74.0,110.2$, $114.3,119.1,123.3,130.4,147.4$.

\subsubsection{Bis [3-(4-methylpheny)limidazolidinyl] Methane 6}

Yield: $98 \%$. M. p. $138^{\circ} \mathrm{C}-140^{\circ} \mathrm{C} .{ }^{1} \mathrm{H}-\mathrm{NMR}\left(\mathrm{CDCl}_{3}\right) \delta$ ppm: 2.25 (s, 6H); 3.12 (t, $4 \mathrm{H}, J=6.37) ; 3.39$ (t, $4 \mathrm{H}, J=$ 6.37); 3.46 (s, 2H); 4.14 (s, 4H); 6.47 (d, $4 \mathrm{H}, J=8.43$ ); 7.04 (d, $4 \mathrm{H}, J=8.43) .{ }^{13} \mathrm{C}$ NMR $\delta$ ppm: $20.2,45.9,50.9$, 69.3, 74.6, 111.8, 125.5, 129.7, 144.6.

\subsection{Antineoplastic Screening}

Compounds 1, 2 were evaluated against 60 human cell lines derived from seven clinically isolated cancer types (lung, colon, melanoma, renal, ovarian, brain and leukemia) according to a standard protocol (conducted at the National Cancer Institute, Bethesda, MD, USA) with the sulforhodamine B (SRB) assay [29-32]. In the present study, it has been evaluated the anti-proliferative activity of the compounds $\mathbf{1}$ - $\mathbf{6}$ on human lung adenocarcinoma epithelial cell line A549, human colon carcinoma cell line HCT116 and human mammary adenocarcinoma cell line MCF-7 according with the NCI protocol.

Peripheral blood was obtained from healthy donors in accordance with local ethical committee approval. The peripheral blood mononuclear cells (PBMC) were isolated by centrifugation through a Ficoll-Hypaque (Pharmacia LKB Biotech., Piscataway, NJ) gradient. Mononuclear cells from peripheral blood (PBMC) were cultured for $48 \mathrm{~h}$ in the presence of the synthesized drugs at a concentration of $10^{-4} \mathrm{M}$ in culture medium RPMI containing 5\% fetal bovine serum, $2 \mathrm{mM} \mathrm{L}$-glutamine and gentamicin in plastic 96-multiwell plates. Controls were performed without the addition of the drugs or cultured in the presence of dimethyl sulfoxide (DMSO). After 48 $\mathrm{h}$, the cells were removed from the wells, washed with cold PBS and resuspended in $400 \mu$ of cold PBS and 100 
$\mu \mathrm{l}$ were transferred to FacScan tubes. FITC-Annexin-V (Becton and Dickinson) was added to the experimental tubes. The samples were mixed by vortex and incubated for 15 minutes at room temperature in the dark. PI and binding buffer were provided in the kit and were added to the samples which were analyzed within one hour by flow cytometry. Dot-plots of PI vs. Annexin-V fluorescence were obtained with the WinMDI 2.9 program and percentages for each population corresponding to the live cells and cells that enter in apoptosis and necrosis were calculated.

\section{Results and Discussion}

In our original procedure compounds $\mathbf{1}$ - $\mathbf{6}$ were synthesized in homogenous phase by condensation of $N$-arylethylenediamines with an excess aqueous formaldehyde $(37 \%)$ in ethanol under reflux [18]. Precursor $N$-arylethylenediamines were prepared by aminolysis of 2bromoethylamine (hydrobromide) with the corresponding arylamine [33].

In recent years, heterogeneous catalysts have attracted attention as catalysts for a variety of organic reactions. The use of solid acid catalyst instead of liquids includes many advantages, such as reduced equipment corrosion, ease of product isolation, and environmental acceptability. Amberlist-15 is a macroporous acidic ion-exchange resin that presents several advantages. In this regard Amberlyst 15 possesses properties such as non-hazardous, chemical and physical stability and can be recycled and used over a prolonged period. It catalyzes a wide variety of reactions in heterogeneous phase [24-36], and recently was used for the synthesis of bis (heterocyclyl) methane derivatives from heteroaryl species and carbonyl substrates [37].

In this work we present the synthesis of bis-derivatives 1 - $\mathbf{6}$ in heterogeneous phase using trioxane as source of formaldehyde and Amberlyst-15 as catalyst (Scheme 1).

The reactions were performed by heating a mixture of the corresponding $N$-arylethylenediamine, trioxane and the resin in DCM (dichloromethane) under reflux for a period as indicated in Table 1. After filtration and evaporation of the solvent compounds $\mathbf{1}$ - $\mathbf{6}$ were obtained with excellent yields (Table 1). The catalyst could be recycled by refluxing in DCM and consecutively reused after activation for tree times with similar yields.

Bis (3-phenylimidazolidinyl-1) methane (1) and bis [3(4-methoxyphenyl) imidazolidinyl-1] methane (2) were selected by the National Cancer Institute (NCI) for the in vitro cell line screening to investigate their anticancer activity. These compounds were evaluated against 60 human cell lines derived from seven clinically isolated cancer types (lung, colon, melanoma, renal, ovarian, brain and leukemia) according to a standard protocol (conducted at the National Cancer Institute, Bethesda,
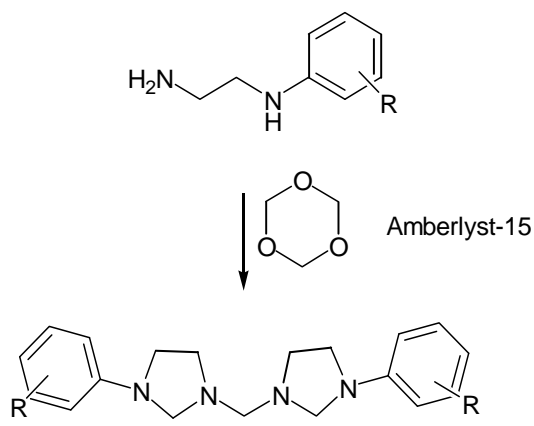

1-6

Scheme 1. Synthesis of bis (3-arylimidazolidinyl-1) methanes derivatives.

Table 1. Synthesized compounds1 - 6 .

\begin{tabular}{cccc}
\hline Compound & $\mathrm{R}$ & Time (min) & Yield (\%) \\
\hline $\mathbf{1}$ & $\mathrm{H}$ & 17 & 96 \\
$\mathbf{2}$ & $4-\mathrm{CH}_{3} \mathrm{O}$ & 19 & 95 \\
$\mathbf{3}$ & $4-\mathrm{Cl}$ & 27 & 98 \\
$\mathbf{4}$ & $3,4-\mathrm{Cl}_{2}$ & 25 & 96 \\
$\mathbf{5}$ & $3-\mathrm{Br}$ & 15 & 97 \\
$\mathbf{6}$ & $4-\mathrm{CH}_{3}$ & 18 & 95 \\
\hline
\end{tabular}

MD, USA) with the sulforhodamine B (SRB) assay [21-24]. The evaluated compounds 1 y 2 showed antitumor activity for the leukemia cells lines CCRF-CEM, K-562, MOLT-4 and RPMI 8226; for non-small cell lung cancer HOP-92, NCI-H23; colon cancer HCC-2998, HCT-15, SW-620; melanoma LOX IMVI cell line, IGROV1 ovarian cancer and renal cancer A486 and ACHN. The growth inhibitory activity and GI50 data are presented in Table 2.

Considering the above results obtained for the compounds $\mathbf{1}$ and $\mathbf{2}$ it was performed the NCI assay with the compounds 3 - $\mathbf{6}$ on 3 different human cell lines. In our laboratory, it was studied the anti-proliferative activity of the compounds $\mathbf{1}$ - $\mathbf{6}$ on human lung adenocarcinoma epithelial cell line A549, human colon carcinoma cell line HCT116 and human mammary adenocarcinoma cell line MCF-7 according with the NCI protocol. Percentage growth inhibition was calculated as:

$[(\mathrm{Ti}-\mathrm{Tz}) /(\mathrm{C}-\mathrm{Tz})] \times 100$ for concentrations for which $\mathrm{Ti} \geq \mathrm{Tz} ;[(\mathrm{Ti}-\mathrm{Tz}) / \mathrm{Tz}] \times 100$ for concentrations for which $\mathrm{Ti}<\mathrm{Tz}$. [Tz: time zero, $\mathrm{C}$ : control growth, and $\mathrm{Ti}$ : test growth in the presence of drug at the five concentration levels].Growth inhibition of 50\% (GI50) was calculated from

$$
[(\mathrm{Ti}-\mathrm{Tz}) /(C-\mathrm{Tz})] \times 100=50,
$$

which was the drug concentration resulting in a $50 \%$ re- 
Table 2. Antiproliferative activity of compounds 1 - 2 (NCI results).

\begin{tabular}{|c|c|c|c|c|}
\hline \multirow{2}{*}{ Cell line } & \multicolumn{2}{|c|}{ Compound 1} & \multicolumn{2}{|c|}{ Compound 2} \\
\hline & $\% \mathrm{G} 1 \times 10^{-4} \mathrm{M}$ & $\mathrm{GI}_{50}{ }^{*}$ & $\% \mathrm{G} 1 \times 10^{-4} \mathrm{M}$ & $\mathrm{GI}_{50}$ \\
\hline CCRF-CEM & 22 & $4.20 \times 10^{-5}$ & 10 & $3.34 \times 10^{-5}$ \\
\hline K-562 & 48 & $3.90 \times 10^{-6}$ & -50 & $2.78 \times 10^{-5}$ \\
\hline MOLT-4 & 37 & $2.36 \times 10^{-5}$ & -45 & $1.23 \times 10^{-5}$ \\
\hline RPMI-8226 & 35 & $6.09 \times 10^{-5}$ & 1 & $3.26 \times 10^{-5}$ \\
\hline HOP-92 & 85 & $>1.00 \times 10^{-4}$ & 46 & $8.15 \times 10^{-5}$ \\
\hline NCI-H23 & 73 & $>1.00 \times 10^{-4}$ & 38 & $4.80 \times 10^{-5}$ \\
\hline HCC-2998 & 62 & $>1.00 \times 10^{-4}$ & 38 & $5.04 \times 10^{-5}$ \\
\hline HCT-15 & 51 & $>1.00 \times 10^{-4}$ & 11 & $3.70 \times 10^{-5}$ \\
\hline SW-620 & 30 & $6.07 \times 10^{-5}$ & 2 & $2.82 \times 10^{-5}$ \\
\hline LOX IMVI & 41 & $6.86 \times 10^{-5}$ & 23 & $4.13 \times 10^{-5}$ \\
\hline IGROV1 & 31 & $2.56 \times 10^{-5}$ & 12 & $1.70 \times 10^{-6}$ \\
\hline A498 & 8 & $3.72 \times 10^{-5}$ & 7 & $1.82 \times 10^{-5}$ \\
\hline $\mathrm{ACHN}$ & 30 & $5.40 \times 10^{-5}$ & -1 & $3.36 \times 10^{-5}$ \\
\hline
\end{tabular}

${ }^{*}$ GI50 value is the concentration that results in $50 \%$ decrease in the cell growth relative to an untreated control.

duction in the net protein increase (as measured by SRBstaining) in control cells during the drug incubation. The drug concentration resulting in total growth inhibition (TGI) was calculated from $\mathrm{Ti}=\mathrm{Tz}$. The LC50 (concentration of drug resulting in a $50 \%$ reduction in the measured protein at the end of the drug treatment as compared to that at the beginning) indicating a net loss of cells following treatment that was calculated from $[(\mathrm{Ti}-\mathrm{Tz}) / \mathrm{Tz}] \times 100=-50$. Values were calculated for each of these three parameters if the level of activity was reached; however, if the effect was not reached or was exceeded, the value for that parameter was expressed as greater or less than the maximum or minimum concentration tested.

When the compounds $\mathbf{1}$ - $\mathbf{6}$ were assayed with different cell lines it was observed, in general, a potent inhibitory activity (Table 3 and Figures 1-3).

In Figures $\mathbf{4}$ and $\mathbf{5}$ it is shown the dose-response curves for the six compounds for different drug concentrations, indicating that in all the cases it is possible to observe a dependence of the response with the concentration.

In order to study the apoptotic process that the cells suffer with the different drug treatment, it was consulted the Beckton and Dickinson manual for the use of Annexin-V-propidium iodine. Loss of plasma membrane asymmetry is one of the earliest features of apoptosis: the membrane phospholipid phosphatidylserine (PS) is translocated from the inner to the outer leaflet of the plasma membrane, thereby exposing PS to the external cellular environment. Annexin V is a $35-36 \mathrm{kDa} \mathrm{Ca}{ }^{2+}$-dependent phospholipid-binding protein with high affinity for PS, and binds to exposed apoptotic cell surface PS.

In order to test the toxicity of the drugs, it was performed an experiment to detect apoptosis and necrosis in peripheral blood mononuclear cells (PBMC)that can be considered as a normal cell population, with the Annexin-V PI kit and analysis of this phenomenon by flow cytometry. The results showed that drugs 2 and 4 were toxic at the concentration of $10^{-4} \mathrm{M}$ obtaining high percentages of apoptosis. The other drugs showed a percentage lower than $15 \%$ of apoptosis and necrosis and can be considered nontoxic (Figure 6).

Results can be summarized as follows:

Compounds 2, showed antiproliferative activity mainly for the cell lines studied by the NCI but they were toxic for normal cells (37\% apoptosis). Drug 4 also presented the greater antineoplastic activity in the three cells lines showed in the Figures 1-3 but it was very toxic for normal cells ( $57 \%$ apoptosis).

Compounds 1, 3, 5 and 6 were not cytotoxic in primary cultures of PBMC and they showed different antineoplastic activity for the studied cell lines of different origin. It was possible to find a correlation between the substitution of the compounds and the sensitivity of the cell lines. The parent compound, bis (3-phenylimidazolidinyl-1) methane 1 showed antineoplastic activity on the leukemia cell lines CCRF-CEM, K562 and MOLT-4, on the ovarian cancer cell line A-498, on ACHN, on lung cell lines and on colon cell line. Nevertheless, it was not 
Table 3. Percentage growth inhibition of compounds $1-6,1 \times 10^{-4} \mathrm{M}$.

\begin{tabular}{cccccccc}
\hline Cell line & Compound 1 & Compound 2 & Compound 3 & Compound 4 & Compound 5 & Compound 6 \\
\hline A549 & $46 \%$ & $54 \%$ & $46 \%$ & $74 \%$ & $50 \%$ & $73 \%$ \\
HCT116 & $60 \%$ & $53 \%$ & $82 \%$ & $100 \%$ & $89 \%$ & $23 \%$ \\
MCF-7 & $9 \%$ & $57 \%$ & $47 \%$ & $85 \%$ & $46 \%$ & $62 \%$ \\
\hline
\end{tabular}

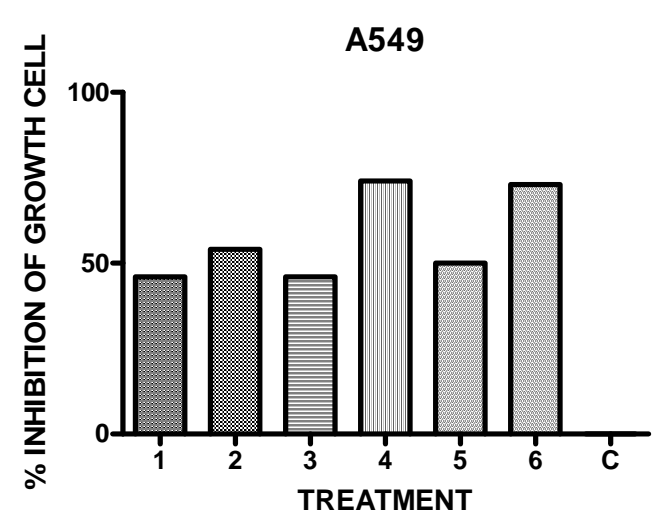

Figure 1. In vitro antineoplastic activity of the drugs in comparison with the full growth $\mathbf{C}$ for the human lung adenocarcinoma A549 $(n=6)$.

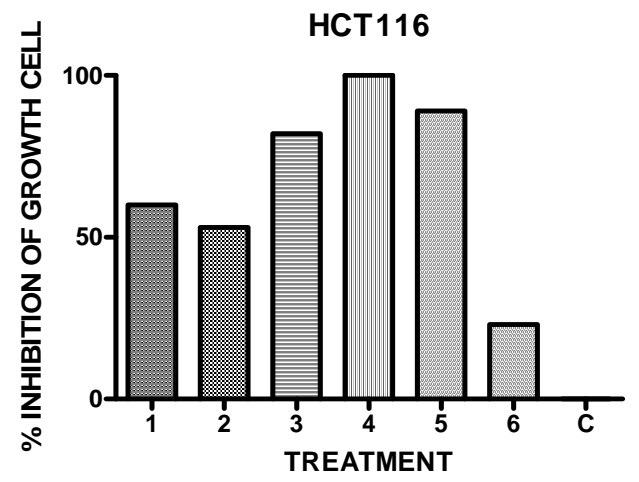

Figure 2. In vitro antineoplastic activity of the drugs in comparison with the full growth $\mathrm{C}$ for the human colon adenocarcinoma HCT116 $(n=9)$.

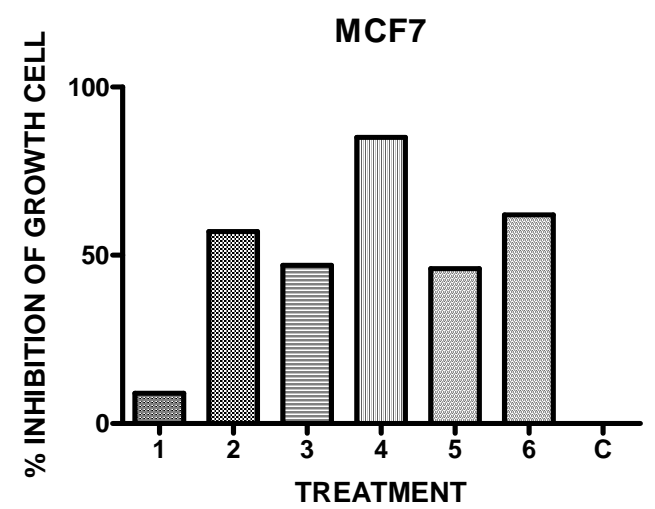

Figure 3. In vitro antineoplastic activity of the drugs in comparison with the full growth $\mathrm{C}$ for the human mammary adenocarcinoma MCF-7 $(n=9)$.

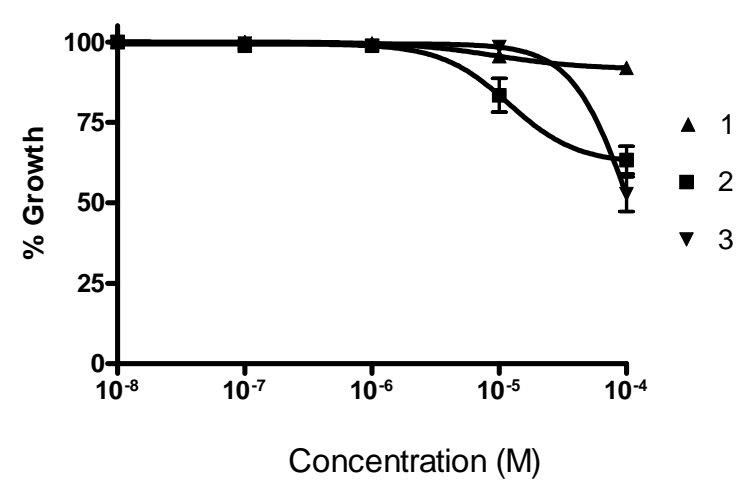

Figure 4. Doses response curve for compounds 1 - 3 in a MCF-7 growth inhibition experiment $(n=9)$.

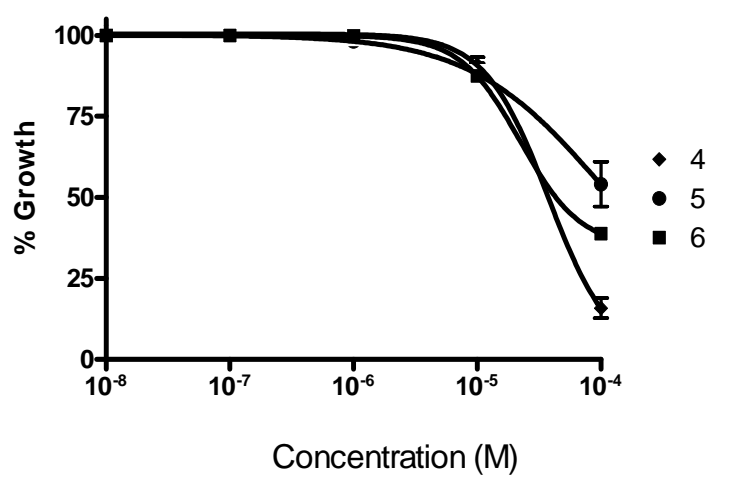

Figure 5. Doses response curve for compounds 4 - 6 in a MCF-7 growth inhibition experiment $(n=9)$.

\section{TOXICITY ASSAY}

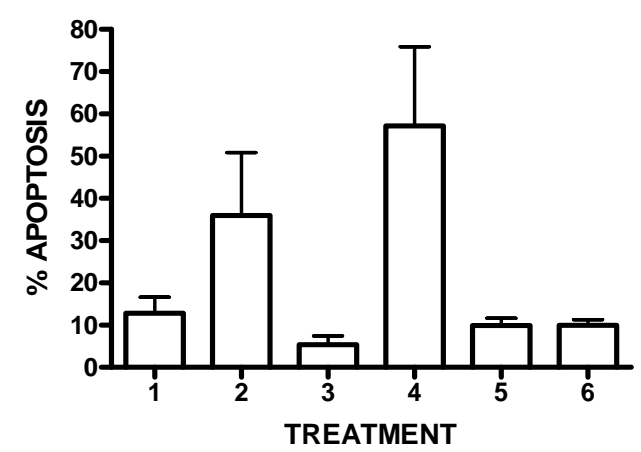

Figure 6. Cytotoxicity of the experimental drugs on normal PBMC. The percentage of apoptosis and necrosis was determined in an Annexin-V PI assay and analyzed by flow cytometry $(n=3)$. The values for the basal without the addition of the drugs and the control of DMSO were substracted for each treatment. 
possible to detect antineoplastic activity on the human mammary cell line MCF-7.The monohalogenated derivatives 4-chlorophenyl $\mathbf{3}$ and 3-bromophenyl $\mathbf{5}$ showed a similar activity on the lung $(46 \%, 50 \%$ inhibition of growth cell), and mammary cell lines (47\%, 46\% inhibition growth cell). These derivatives showed a potent and selective activity represented by $82 \%$ and $89 \%$ inhibition growth cell on the colon cell line. The 4-tolyl derivative 6 presented an inhibitory activity reaching a value of $73 \%$ inhibition of growth cell on lung adenocarcinoma cell line and $62 \%$ on mammary cell line.

Considering the above results and in relation with a Structure Activity Correlation it was observed that a methyl substituent in the aromatics rings increases the anti-neoplastic activity on lung adenocarcinoma cell line (A549) and mammary cell line (MCF-7). The monosubstitution on the aromatics rings by halogen (chloro, bromo) increases selectively the activity for the human colon cell line (HCT116).

\section{Conclusion}

We have developed a new and simple protocol to prepare a series of bis (3-arylimidazolidinyl-1) methanes 1 - $\mathbf{6}$ using trioxane as a source of formaldehyde, and Amberlyst-15 as an efficient catalyst. Compounds were tested with the Sulforhodamine B assay according to the NCI assay for several cell lines and evaluated cytotoxicity on normal cells using the Annexin-PI staining and flow cytometry. In some cases (compounds $\mathbf{1}, \mathbf{3}, \mathbf{5}$ and $\mathbf{6}$ ) we found antineoplastic activity without toxic effects.

\section{Acknowledgements}

This study was financially supported by the Universidad de Buenos Aires.

\section{REFERENCES}

[1] J. B. Gibbs, "Mechanism-Based Target Identification and Drug Discovery in Cancer Research," Science, Vol. 287, No. 5466, 2000, pp. 1969-1973. http://dx.doi.org/10.1126/science.287.5460.1969

[2] C. Unger, "New Therapeutic Approaches in Cancer Treatment," Drugs of the Future, Vol. 22, No. 12, 1997, pp. 1337-1345.

[3] P. Heffeter, M. A. Jacupec, W. Orner, S. Wild, N. G. Keyserlingk, L. Elbling, H. Zorbas, A. Korynevska, S. Knasmuller, H. Sutterluty, M. Micksche, B. K. Keppler and W. Berger, "Anticancer Activity of the Lanthanum Compound [Tris(1,10-phenanthroline) lanthanum(III)] trithiocyanate (KP772; FFC24)," Biochemical Pharmacology, Vol. 71, No. 4, 2006, pp. 426-440. http://dx.doi.org/10.1016/j.bcp.2005.11.009

[4] J. Mann, A. Baron, Y. Opoku-Boahen, E. Johansson, G. Parkinson, L. R. Kelland and S. Neidle, "A New Class of Symmetric Bis-Benzimidazole-Based DNA Minor Groove
Binding Agents," Journal of Medicinal Chemistry, Vol. 44, No. 2, 2001, pp. 138-144.

http://dx.doi.org/10.1021/jm000297b

[5] A. Seaton, C. Higgins, J. Mann, A. Baron, C. Bailly, S. Neidle and H. van den Berg, "Mechanistic and Anti-Proliferative Studies of Two Novel, Biologically Active BisBenzimidazoles," European Journal of Cancer, Vol. 39, No. 17, 2003, pp. 2548-2555.

http://dx.doi.org/10.1016/S0959-8049(03)00621-X

[6] Y.-H. Yang, M.-S. Cheng, Q.-H. Wang, H. Nie, N. Liao, J. Wang and H. Chen, "Design, Synthesis, and Anti-Tumor Evaluation of Novel Symmetrical Bis-Benzimidazole," European Journal of Medicinal Chemistry, Vol. 44, No. 17, 2009, pp. 1808-1812. http://dx.doi.org/10.1016/j.ejmech.2008.07.021

[7] H. A. Johnson and N. R. Thomas, "Polyhydroxylatedazepanes as New Motifs for DNA Minor Groove Binding Agents," Bioorganic \& Medicinal Chemistry Letters, Vol. 12, No. 2, 2002, pp. 237-241. http://dx.doi.org/10.1016/S0960-894X(01)00719-3

[8] E. Rajanarendar, M. N. Reddy, S. R. Krishna, K. G. Reddy, Y. N. Reddy and M. V. Rajam, "Design, SyntheSis, in Vitroantimicrobial And Anticancer Activity Of Novel Methylenebis-Isoxazolo[4,5-B]Azepines Derivatives," European Journal of Medicinal Chemistry, Vol. 50, 2012, pp. 344-349.

http://dx.doi.org/10.1016/j.ejmech.2012.02.013

[9] L. W. Deady, J. Desneves, A. J. Kaye, G. J. Finlay, B. C. Baguley and W. A. Denny, "Synthesis and Antitumor Activity of Some Indeno[1,2-b]Quinolone-Based Biscarboxamides," Bioorganic \& Medicinal Chemistry, Vol. 8, No. 5, 2000, pp. 977-984. http://dx.doi.org/10.1016/S0968-0896(00)00039-0

[10] R. Sánchez-Martín, J. M. Campos, A. Conejo-García, O. Cruz-López, M. Báñez-Coronel, A. Rodríguez-González, M. A. Gallo, J. C. Lacal and A. Espinosa, "Symmetrical Bis-Quinolinium Compounds: New Human Choline Kinase Inhibitors with Antiproliferative Activity against the HT-29 Cell Line," European Journal of Medicinal Chemistry, Vol. 48, No. 9, 2005, pp. 3354-3363.

[11] S. Safe, S. Papineni and S. Chintharlapalli, "Cancer Chemotherapy with Indole-3-Carbinol, Bis(3'-Indolyl)-Methane and Synthetic Analogs," Cancer Letters, Vol. 269, No. 2, 2008, pp. 326-338.

http://dx.doi.org/10.1016/j.canlet.2008.04.021

[12] S. D. Cho, S. Chintharlapalli, M. Abdelrahim, S. Papineni, S. Liu, J. Guo, P. Lei, A. Abudayyeh and S. Safe, "5,5'-Dibromo-Bis(3'-Indolyl)Methane Induces KrüppelLike Factor 4 and p21 in Colon Cancer Cells," Molecular Cancer Therapeutics, Vol. 7, No. 7, 2008, pp. 2109-2120. http://dx.doi.org/10.1158/1535-7163.MCT-07-2311

[13] D. Bigg, S. Auvin, C. Lanco and G. Prevost, "Imidazolidine-2,4-Dione Derivatives and Use Thereof as a Medicament,"WO2010119194, 2010.

[14] G. Prevost, S. Auvin, C. Lanco, A. Liberatore and O. Lavergne, "Imidazolidine-2,4-Dione Derivatives, and Use Thereof as a Cancer Drugs," EP 2419 410, 2013.

[15] P. Y. Johnson and D. J. Kerkman, "The Chemistry of Hindered Systems. II. The Acyloin Reaction-An Ap- 
proach to Regiospecifically Hydroxylated Tetramethylazacycloheptane Systems," The Journal of Organic Chemistry, Vol. 41, No. 10, 1976, pp. 1768-1773. http://dx.doi.org/10.1021/jo00872a023

[16] P. Calabresi and J. Darnowski, "Use of Taurolidine to Treat Tumors," US 6,429, 224, 2002.

[17] P. Calabresi, F. A. Goulette and J. W. Darnowski, "Taurolidine: Cytotoxic and Mechanistic Evaluation as a Novel Antineoplastic Agent," Cancer Research, Vol. 61, No. 18, 2001, pp. 6816-6821.

[18] I. Perillo, E. Repetto, M. C. Caterina, R. Massa, G. Gutkind and A. Salerno, "Synthesis, Spectroscopic and Biological Properties of Bis(3-Arylimidazolidinyl-1)Methanes. A Novel Family of Antimicrobial Agents," European Journal of Medicinal Chemistry, Vol. 40, No. 8, 2005, pp. 811-815. http://dx.doi.org/10.1016/j.ejmech.2005.03.010

[19] V. Sharma and M. S. Y. Khan, "Synthesis of Novel Tetrahydroimidazole Derivatives and Studies for Their Biological Properties," European Journal of Medicinal Chemistry, Vol. 36, No. 6, 2001, pp. 651-658. http://dx.doi.org/10.1016/S0223-5234(01)01256-9

[20] W. E. Craig and J. O. Van Hook, "Heterocyclic Aminoalkil Imidazolidines and Hexahidropyrimidines," US 2,675, 381, 1954.

[21] J. O. Van Hook and W. E. Craig, "N,N'-Bis(Aminoalkil) Derivatives of Imidazolines and Hexahidropyrimidines," US 2,675, 387, 1954.

[22] M. C. Caterina, I. A. Perillo, L. Boiani, H. Pezaroglo, H. Cerecetto, M. Gonzalez and A. Salerno, "Imidazolidines as New Anti-Trypanosoma Cruzi Agents: Biological Evaluation and Structure-Activity Relationships," Bioorganic \& Medicinal Chemistry, Vol. 16, No. 5, 2008, pp. 2226-2234.

[23] M. C. Caterina, M. V. Corona, I. A. Perillo, A. Salerno, D. Benítez, H. Cerecetto and M. González, "Síntesis y Evaluación in Vitro Frente a T. Cruzi de 1-Acil-3-Arilimidazolidinas," 3er Workshop Argentino de Química Medicinal, Argentina, 2008, p. 47.

[24] G. S. de Carvalho, P. A. Machado, D. T. S. de Paula, E. S. Coimbra and A. D. da Silva, "Synthesis, Cytotoxicity, and Antileishmanial Activity of N,N'-Disubstitutedethylenediamine and Imidazolidine Derivatives," The Scientific World Journal, Vol. 10, 2010, pp. 1723-1728. http://dx.doi.org/10.1100/tsw.2010.176

[25] E. von Angerer, G. Kranzfelder, A. K. Taneja and H. Schönenberger, "N,N'-Dialkyl Bis(Dichorophenyl) Ethylenediamines and Imidazolidines: Relationship between Structure and Estradiol Receptor Affinity," Journal of Medicinal Chemistry, Vol. 23, No. 12, 1980, pp. 13471350. http://dx.doi.org/10.1021/jm00186a012

[26] E. von Angerer, G. Egginger, G. Kranzfelder, H. Bernhauser and H. Schönemberger, "N,N'-Dialkyl-1, 2-Bis(Hydroxyphenyl) Ethylenediamines and N,N'-Dialkyl-4,5-Bis(4-Hydroxyphenyl)Imidazolidines: Synthesis and Evaluation of
Their Mammary Tumor Inhibitingactivity," Journal of Medicinal Chemistry, Vol. 25, No. 7, 1982, pp. 832-837. http://dx.doi.org/10.1021/jm00349a013

[27] H. A. Nieper, "New Carcinostatic Compounds against Hela Cells," ArztlForsch, Vol. 20, 1966, pp. 18-23.

[28] K. Sztanke, S. Fidecka, E. Kedzierska, Z. Karczmarzyk, K. Pihlaja and D. Matosiuk, "Antinociceptive Activity of New Imidazolidine Carbonyl Derivatives. Part 4. Synthesis and Pharmacological Activity of 8-Aryl-3,4-Dioxo2H,8H-6,7-Dihydroimidazo[2,1-c] [1,2,4]Triazines," European Journal of Medicinal Chemistry, Vol. 40, No. 2, 2005, pp. 127-134. http://dx.doi.org/10.1016/j.ejmech.2004.09.020

[29] P. Skehan, R. Storeng, D. Scudiero, A. Monks, J. McMahon, D. Vistica, J. T. Warren, H. Bokesch, S. Kenney and M. R. Boyd, "New Colorimetric Cytotoxicity Assay for Anticancer-Drug Screening," Journal of the National Cancer Institute, Vol. 82, No. 13, 1990, pp. 1107-1112. http://dx.doi.org/10.1093/jnci/82.13.1107

[30] M. R. Grever, S. A. Schepartz and B. A. Chabner, "The National Cancer Institute: Cancer Drug Discovery and Development Program," Seminars in Oncology, Vol. 19, No. 6, 1992, pp. 622-638.

[31] R. H. Shoemaker, "The NCI60 Human Tumour Cell Line Anticancer Drug Screen," Nature Reviews Cancer, Vol. 6, No. 10, 2006, pp. 813-823.

http://dx.doi.org/10.1038/nrc1951

[32] J. S. Driscoll, "The Preclinical New Drug Research," Cancer Treatment. Reports, Vol. 68, No. 1, 1984, pp. 6367.

[33] I. Perillo, M. C. Caterina, J. Lopez and A. Salerno, "Synthesis of Substituted 1H-4,5-Dihydroimazolium Salt by Dehydrogenation of Imidazolidines," Synthesis, No. 6, 2004, pp. 851-856.

[34] Y.-H. Liu, Q.-S. Liu and Z.-H. Zhang, "Amberlyst-15 as a New Andreusable Catalyst for Regioselective RingOpening Reactions of Epoxides to Alcoxy Alcohols," Journal of Molecular Catalysis A: Chemical, Vol. 296, No. 1, 2008, pp. 42-46.

[35] L. D. Sasiambarrena, A. S. Cánepa and R. D. Bravo, "Synthesis of 1,2,4,5-Tetrahydro-3,2-Benzothiazepine 3,3-Dioxides Using Amberlyst-15," Synthetic Communications, Vol. 41, No. 2, 2010, pp. 200-205. http://dx.doi.org/10.1080/00397910903533983

[36] R. Pal, T. Sarka and S. Khasnobis, "Amberlyst-15 in Organic Synthesis," Arkivoc, Vol. 2012, No. 1, 2012, pp. 570-609. http://dx.doi.org/10.3998/ark.5550190.0013.114

[37] K. Singh, S. Sharma and A. Sharma, "Unique Versatility of Amberlyst 15. An Acid and Solvent-Free Paradigm towards Synthesis of Bis(Heterocyclyl)Methane Derivatives," Journal of Molecular Catalysis A: Chemical, Vol. 347, No. 1, 2011, pp. 34-37. http://dx.doi.org/10.1016/j.molcata.2011.07.007 